IDEAS IN ECRLGGY AND EVRLutION 7: 43-55, 2014

doi:10.4033/iee.2014.7.11.c

(C) 2014 The Author. (C) Ideas in Ecology and Evolution 2014 Received 14 January 2014; Accepted 16 May 2014

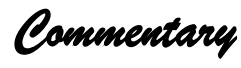

\title{
Indigenous sciences are not pseudosciences
}

\author{
Root Gorelick \\ Root Gorelick (Root.Gorelick@carleton.ca), Department of Biology, School of Mathematics \& Statistics, and \\ Institute of Interdisciplinary Studies, Carleton University, 1125 Colonel By, Ottawa, ON K1S 5 B6 Canada
}

\begin{abstract}
Given how difficult it is to define science, it is surprising how readily many people consider Indigenous sciences to be pseudoscience. I review definitions of indigenous science, as well as science and pseudoscience. I then proffer that either western or indigenous science is any broadly Bayesian undertaking, i.e. testing and updating hypotheses (prior and posterior probabilities) based on observed data. Western and indigenous sciences simply have different priors, ask different questions, and sometimes use different data, hence they may make very different predictions about very different phenomena. Indigenous sciences seem to have no more myth than do western sciences. I provide examples of where western and indigenous sciences may provide complementary approaches for understanding ecology and evolution.
\end{abstract}

\section{Introduction}

Too often indigenous sciences are construed as pseudoscience, despite being as sophisticated and nuanced as western sciences. See, for example, definitive tomes such as Cajete's (2000) Native Science and Pierotti's (2011) Indigenous Knowledge, Ecology, and Evolutionary Biology. Indigenous sciences may often be dismissed as heterodox given how socially, economically, and politically dominant people of European heritage have become in the Americas and elsewhere around the world, despite Europeans having had no historical, cultural, economic, technological, or intellectual adventages over other peoples (Blaut 1993). Indigenous knowledge and indigenous peoples are still here. Mayan populations are possibly larger now than they have ever been (Cajete 2000). By any standard, the Iroquois Five/Six Nations Confederacy flourished during the first three centuries of North American colonialism, including substantial interactions with Europeans from at least the late 1600s (Johansen 1982). The Iroquois Confederacy played a major role in the American revolutionary war of 1775-1782, despite over a century of previous exposure to European weapons and diseases (Grinde 1977). During the late 1700s, the Iroquois and Cherokee outnumbered people of European descent in North America, and Iroquois militaries were tactically and maybe even technologically superior to those of the British, French, and Americans (Johansen 1982). To this day, the Six Nations of the Iroquois Confederacy are important and vibrant nations (Alfred 1999), although their population numbers have decreased since the late 1700s (George-Kanentiio 1995). Note that counting population numbers is itself a very European and essentialist thing to do, with many indigenous peoples considering each individual to be unique (Christie 1993). Despite all of this, indigenous sciences are too often construed as pseudoscience, aka myth or fable, a notion that I wish to firmly dispel here.

[In the original submission of the above paragraph, I erroneously and uncritically accepted the EuroAmerican notion that Jared Diamond (1997) popularized in his book Guns, Germs, and Steel that European colonists had superior technology in their weapons and superior immunity to diseases. Both reviewers compellingly admonished me for this error. For instance, I originally stated that, "Pierotti (2011) hypothesized that immunity to smallpox was not purely luck, but rather that only Europeans tended to sleep with domesticated farm animals during cold winters, thereby developing an immunity to smallpox." While undoubtedly there was truth to Europeans using germ warfare in giving to indigenous peoples blankets that were knowingly infected with smallpox, data and history show that Europeans did not accrue a huge technological advantage over 
indigenous North American peoples. My error in uncritically accepting the European advantages of guns and immunity to diseases, especially from a western scientist, was sufficiently egregious that I re-wrote the above paragraph, in a way that is more respectful and is not redundant with Marie-Eve Drouin-Gagné's brilliant response (2014).]

In many practical ways, North American (Turtle Island) sciences have surpassed western sciences. For example, much more is known about elusive Greenland sharks (Somniosus microcephalus, aka Iqalukjuaq in Inuktitut) by Inuit fishers than westerners (Idrobo and Berkes 2012). Undoubtedly this has something to do with actually seeing and living amongst sharks, rather than sitting in front of computers and gene sequencers. Several traditional indigenous plant medicines are only collected at night. I suspect that several such plants have CAM photosynthesis, hence are more acidic at night, which can alter efficacies of medicines. Finding plant medicines is often not serendipitous, but a matter of listening to and watching others, including non-human animals. How do I decide when to tap sugar maples (Acer saccharum)? I don't read a book, look at a calendar, check the weather forecast, or ask commercial producers, but instead watch the grey squirrels (Sciurus carolinensis), which only chew maple buds to release the sugars once the sap is running. "Traditional knowledge is rooted in intimacy with a local landscape where the land itself is the teacher. Plant knowledge comes from watching what the animals eat, how Bear harvests lilies and how Squirrel taps maple trees." (Kimmerer 2003: 101). The best way to learn anything about the behavior of extinct mammoths is via indigenous stories of these grand beasts, oral stories that are usually transmitted with almost no alteration (Leahy 2012). Indigenous people all around the world believe that plants talk to one another. While this may sound like a metaphor, plant roots not only emit chemicals to talk amongst themselves and recognize kin (Gorelick and Marler 2014), but their roots can also emit acoustic signals that neighbouring roots hear and respond to (Gagliano et al. 2012), a result that comes as no surprise to most indigenous scientists, teachers, and Elders.

This paper was motivated by my attempt to offer a biology course on indigenous perspectives in ecology and evolution. This attempt was rebuffed by both the biology department and the faculty of science because the relevant decision makers believed that indigenous science constitutes pseudoscience. I will say more about this below, when discussing putative myths in both indigenous and western sciences.

Before delving into details, it is crucial to set a somewhat anti-essentialist tone. There is no unified indigenous science, not even if we restrict attention to a specific continent, such as North America (Turtle Island) or Australia. There do, however, seem to be fairly general commonalities between most indigenous sciences, which I shall discuss below. Likewise there is no single unified western science. This can be seen in western (Euro-American) science in the debates over which is more important in evolution: selection or drift? Or which is more important in western ecology: competition or cooperation? Similarly, there is no unified eastern science, with there being broad-brush differences between, say, Japanese and Indian sciences (Aikenhead and Ogawa 2007). Therefore, I will refer to 'indigenous sciences' and 'western sciences', conceding that not all of my generalizations will adhere to what I say below, but expect that most will.

\section{What is science?}

One problem with characterizing indigenous sciences is that western philosophers continue to have difficulties demarcating science (Taylor 1996, Pigliucci and Boudry 2013). The world is not as simple as Popper's (1959 [1934]) views that science is that which is falsifiable. This spurred the sophisticated falsificationism of Lakatos (1970) and the sweeping generalist notions of Feyerabend (1975, 2010). Both western and indigenous sciences strive for explanation and prediction (Kawagley 1995, Baker 1996), although, in general, western sciences may place greater emphasis on prediction while indigenous sciences may place greater emphasis on explanation.

For me, science is anything that is Bayesian, sensu lato, which is similar to the statistical evaluation of hypotheses as suggested by sophisticated falsificationism. Both western and indigenous sciences start with prior probabilities (hypotheses), update those priors with new data (observations), to form posterior probabilities (refined 'adaptable' auxiliary hypotheses). To be mathematically more precise, let $P(\mathrm{~A})$ be the (prior) probability of $A$ and $P(\mathrm{~A} \mid \mathrm{B})$ be the conditional (posterior) probability of $A$ given that $B$ has occurred. Then, Bayes' rule states that,

$$
\frac{P(A)}{P(B)}=\frac{P(A \mid B)}{P(B \mid A)} .
$$

Rearranging terms, we get that

$$
P(A \mid B)=P(A) \times \frac{P(B \mid A)}{P(B)} .
$$

Bayes' rule thereby gives us a way to compute the posterior probability $P(\mathrm{~A} \mid \mathrm{B})$ given the prior probability $P(\mathrm{~A})$ and data about what an observation of $B$ tells us about $A$, i.e.,

$$
\frac{P(B \mid A)}{P(B)}
$$


"Probabilism has an attractive feature: instead of simply providing a black-and-white distinction between science and pseudoscience, it provides a continuous scale from poor theories with low probability to good theories with high probability." (Lakatos 1974: 98). While selfreferential, I am using a methodological tool of science, namely Bayes' rule, to help define science itself, conceding that there may be no discrete demarcation between science and pseudoscience.

However, "the typical descriptive unit of scientific achievements is not an isolated hypothesis but rather a research programme. Science is not simply trial and error, a series of conjectures and refutations. 'All swans are white' may be falsified by the discovery of one black swan. But such trivial trial and error does not rank as science" (Lakatos 1974: 99-100). For something to be science, therefore, requires more than a single application of Bayes' rule, but instead a systematic series of applications of it. One such recursive use of Bayes' rule is a Kalman filter, (Gelb 1974, McGrayne 2011). A Kalman filter is a statistical estimate of the state of nature. Either regularly or sporadically, estimates are updated with noisy data. Furthermore, not only are estimates of the state of nature updated in a Kalman filter, but so are estimates of signal-to-noise ratio of input measurements. A Kalman filter is a mathematical tool that first grew to prominence in getting humans to the moon in the late 1960s. Spacecraft contain gyroscopes and accelerometers to measure direction and acceleration, from which one could estimate the location of the spacecraft relative to the start of the trip using numerical integration. GPS did not exist in the 1960s and, even if it did, it would not work as far away as the moon. Mathematical models, including models of instrumentation error, were used to compute estimates of the spacecraft's current location and direction. This is very much akin to theory. But errors propagate, so occasionally astronauts would have to take a measurement, such as the direction out a window to the moon, sun, or earth, using a sextant or similar device. This is very much akin to testing theory with data. The Kalman filter then mathematically resets estimates of location and direction. The key to Kalman filters was simultaneously accounting for both the state variables (e.g. location, direction) and their uncertainties (covariance matrices). A Kalman filter is a metaphor for how science works.

To make another analogy — analogies and metaphors often being at the heart of indigenous philosophies (Christie 1993, Cajete 2000)—western and indigenous sciences are like Euclidean and non-Euclidean geometries (Lobachevski 1840 [1914]). They are both valid ways of knowing, but they start with different axioms hence end with different conceptualizations of the world, in this instance whether zero, one, or an infinite number of parallel lines can go through a given point in two-dimensional space. In other words, is twodimensional space flat or does it have a positive or negative curvature?

Not all science, nor even all western science, is experimental and reductionist. Much science is observational, such as astronomy, geology, and, of particular relevance here, evolution. These fields are still empirical. They can make observations, but usually only of 'natural' experiments. Charles Darwin's early works on geology and evolution, such as Structure and Distribution of Coral Reefs (1842) and Origin of Species by Means of Natural Selection (1859), were solely observational and synthetic, with essentially no experimentation, but are still some of the-best respected works in western science. Natural experiments still matter, such as determining the role of natural selection in the face of hurricanes (Griffith et al. 2008). Much indigenous science is the same way, relying on natural experiments in lieu of reductionist approaches that are often considered disrespectful of the animal being experimented on. In fact, Kawagley (1995) defined native science (synonymous with indigenous science) as synthesis (see the next section for the exact words of his definition).

Both science and religion are in the business of providing explanations of observed phenomenon. To a naïve person like me, what demarcates science is not just providing explanations, but also making predictions. When we tried to explain the ubiquity of sex (meiosis and karyogamy) by asserting that the first sex (1.0-2.5 billion years ago) must have been sex with oneself, we made several readily testable predictions, such as that all living sexual organisms duplicate all their chromosomes as the first step in both meiosis and karyogamy (Gorelick and Carpinone 2009). Not all of my predictions are immediately testable, but I aim for them to be testable within a decade and certainly while I am still alive (Gorelick 2011, 2012). I want to see my predictions falsified; that is the only way we make progress in science. Indigenous scientists also make testable predictions. As Emily Missyabit McAuley assiduously stated in her review of this paper:

Subsistence fishers and hunters, like anyone living off the land, must make accurate predictions of environmental conditions and resource availability in order to collect enough food for the coming year; their survival depends on it. Data and explanations leading to inaccurate predictions are discarded or refined (similar to western hypothesis testing), and are not passed on. Living in close proximity with other individuals, tribes and nations means that data and explanations are often shared and verified orally through social interactions. Traditional knowledge is passed on through the telling of oral histories, allowing knowledge to be accumulated, built upon and modified over generations, in the 
same way that western scientists train young scientists in what is already known so that these young scientists may then add to that body of knowledge through their own studies. In this way, the accumulation and verification of Indigenous knowledge [becomes] much more complex and sophisticated.

Somewhat surprisingly, though, I have found only two published papers that explicitly insisted that indigenous science must be empirically testable (Usher 2000, Bala and Gheverghese Joseph 2007). However, Leroy Little Bear in the forward to Cajete (2000: $x$ ) stated that "Measurement is part of Native American science but does not play the foundational role that it plays in Western science." This seems tantamount to testing, albeit without the Popperian focus of naïve falsificationism. By contrast, some western scientists, such as some population geneticists and some mathematical ecologists, fail to make any readily testable predictions. There is a large amount of western science that seems purely descriptive or explanatory, and not at all predictive e.g. Vogelsberger et al. (2014) in Nature explained the distribution of galaxies in the universe over the past 13 billion years without providing a single prediction.

\section{What are indigenous sciences?}

Western academia, especially western philosophers, have had a very difficult and, at times, divisive view of what is science, so it should come as no surprise that it is difficult defining indigenous science. This is particularly true because indigenous scholars have not made as many attempts to define such a notion. Some social scientists claimed that there is no sharp distinction between western scientific and indigenous knowledge (Agrawal 1995), but I will dismiss that because shades of grey may be good enough (Lakatos 1974). Lack of a well-accepted definition of indigenous sciences is consistent with indigenous knowledge being more local (vice global) than western knowledge, possibly resulting in many different but equally valid conceptualizations of indigenous science. This is very much in contrast to the supposed conformity in western science. "Western science...sought to standardize information so that it could be used by groups of people who did not necessarily live in the same region." (Alessa 2009: 248). Nonetheless, to start a well-meaning conversation, I will here try to synthesize existing views on what are indigenous sciences.

The most concerted attempt to define indigenous science(s) was by Greg Cajete, at the start of his book Native Science. He (Cajete 2000: 2) begins by stating that, "In Native languages there is no word for 'science," but that the concept of science is vitally important. He defines science as a process, as a way of knowing the natural world, which is consistent with most North American indigenous languages being verbbased. Kimmerer (2013) provides a striking example of what it means for language to be verb-based in Potawatomi with the verb 'to be a bay'. Instead of a bay being an inanimate object, it is considered a living being and a verb that is defined by how it interacts with its neighbours. Please pardon me while I try to describe being a bay in English, which means that I will be too noun based: The waters of a bay slosh around with the winds and tides, in a dynamic relationship with a shoreline and with interconnected bodies of water, as well as with the organism that live therein. Verb-based languages are much better for describing relativity and quantum physics than are noun-based languages (Duran 2007). Cajete's implicit definition of science as process is similar to the way John Moore (1999), a western scientist, advocated that we teach biology as a process in his textbook titled Science as a Way of Knowing. Curiously, in English, 'knowledge' seems to be part of a linguistic back-construction: starting as the verb 'to know', converted to the noun 'knowledge', and subsequently converted back to the verb 'acknowledge'.

Demarcation of indigenous science is admittedly different from demarcation of western science. Cajete (2000) and almost all indigenous scientists intentionally included spirituality as an integral part of indigenous science (Brown 1975, Cajete 2000, Pierotti and Wildcat 2000, Cajete 2006), whereas Popper (1959 [1934]) intentionally defined western science so as to exclude religion (N.B. religion and spirituality are not synonymous, but it would be too long a digression to delve into that distinction here). Indigenous sciences include all ways of knowing the natural world. "Western [science] is formulated to study and analyze objectively learned facts to predict and assert control over the forces of nature, while...Native [science] is oriented toward the synthesis of information gathered from interaction with the natural and spiritual worlds, so as to accommodate and live in harmony with natural principles." (Kawagley 1995: 89, italics added). Science technology studies, aka STS, have long recognized that objectivity is not a hallmark of western science (Reid and Traweek 2000). "Scientists in most cases are not even aware of how deeply embedded our own science is in cultural suppositions that are not universal." (Brown 1975: 38). Many working western scientists erroneously assume that there are kinds of science that do not have a belief component or cultural context, a point rejected by philosophers such as Feyerabend (1987) and Norton (2005). The issue brings to mind Holmes's (1996: 380) observation that Westerners are often unable to understand indigenous values or cosmologies, except as either 'myth' or 'data'. The objection to spiritualism is merely an excuse to denigrate traditional knowledge; the real issue is resource 
management power and legitimacy." (Berkes 2012: 270-271; italics in original).

"Western science and society perpetuate the illusion of 'objective' detachment" (Cajete 2006: 259). "When speaking about Indigenous or Native science, one is really talking about the entire edifice of Indigenous knowledge.... Indigenous science encompasses all of the kinds of knowledge that are part of an Indigenous mindset, which is essentially relational. Thus, the terms 'knowledge' and 'science' are used interchangeably among Indigenous scientists" (Cajete 2000: 3-4). Note, however, that even indigenous scientists consider that there is a demarcation between indigenous science and indigenous religion (Cajete 2006), but that both contain elements of spirituality, in much the same way that western sciences and western religions both contain environmental ethics.

More pertinent to evolution and ecology, Cajete (2000: 4) stated,

Native science is most akin to what Western science calls environmental science or ecology. And while Native people don't have a particular word for either of those Western terms, they certainly have an understanding of the practice of those disciplines of Western science at the individual and communal levels. And so this understanding that Indigenous people have is a very particular and very profound relationship to the natural world. This relationship is predicated on the fact that all Indigenous tribes-their philosophies, cultural ways of life, customs, language, all aspects of their cultural being in one way or another-are ultimately tied to the relationships that they have established and applied during their history with regard to certain places and to the earth as a whole.

"Indigenous science is almost always relational" (Baker 1996: 19). Cajete, Baker, and several others were very much speaking of oikos, whether that be ecology or economics.

Another major defining feature of indigenous sciences is the lack of distinction between observer and observed. "A culturally mediated lens based on 'participation with nature' is the view from which Native science has evolved... Participation provides the grounding for the way of Native science" (Cajete 2000: 4). By contrast, "Western Science is non-participatory" (Rice n.d.: 4), again with the exception of modern western physics, especially quantum physics. What did ecosystems look like without human influence? Is there any way for humans to answer this? Should designated wilderness areas and national parks include humans, especially in the form of indigenous management so as maintain the interactions that had structured those ecosystems for millennia?
As alluded to above, most western perspectives are absolute, whereas indigenous perspectives are relational (Baker 1996, Cajete 2000, Wilson 2008). This could be re-phrased as western science being Newtonian (except for relativity theory in physics, but physics always presents philosophical conundrums for western science). Western perspectives of space are global, whereas indigenous perspectives of space are local (Alessa 2009, Pierotti 2011). Western perspectives of time are linear, whereas indigenous perspectives of time are cyclical (Verran 1998, Law 2004). Both western and indigenous sciences conduct generalized Bayesian updating of their auxiliary hypotheses, but from very different hardcore assumptions sensu Lakatos (1970). Thus, in a course in indigenous perspectives in ecology and evolution, indigenous and non-indigenous students had very different notions about our university's annual butterfly show. This event brings in thousands of school children to watch butterflies forage in our greenhouse. Western students found this extraordinarily educational. Indigenous students found this utterly disrespectful and a waste. The butterflies were bred and raised by commercial growers in the UK, far from their native habitats, then flown as pupae to Canada, imported with the agricultural proviso that the animals not be released nor breed in Canada. The butterfly show was the captive end of a lineage, without even a clear research benefit. Time was no longer cyclical for the butterflies, and their local traditions had been tragically disrupted.

Even though indigenous sciences are usually considered more relational than western sciences (except for modern physics), Baker (1996: 19) argued that otherwise there may not be any fundamental differences between indigenous and western sciences:

....indigenous science differs from 'western' science in its method and rigour, but not in its essential nature. Like 'western' science, indigenous science consists of a set of explanations which seek to make sense of the natural world and which are consistent with a particular worldview. Through an informal process of theory, experimentation and replication these explanations have been validated, and have become part of the oral tradition of a specific indigenous group, often becoming most visible in their technological applications.

Again we see that there may be lack of appreciation and lack of understanding of indigenous sciences simply because western scientists and philosophers do not understand or devalue oral traditions.

Because indigenous science is not necessarily well defined, maybe it makes sense to be less ambitious and instead define Traditional Ecological Knowledge (TEK). However, TEK is also usually not defined or is vaguely defined. TEK has even been described as 
"fuzzy knowledge", with the caveat that this can and often does refer to the technically precise notion of fuzzy logic (Alessa 2009, Berkes and Berkes 2009). One of the reviewers suggested papers in which TEK was defined, but these definitions were not as satisfactory as I would have liked. For example:

- "We have therefore developed a working definition of Traditional Ecological Knowledge as a cumulative body of knowledge, practice, and belief, evolving by adaptive processes and handed down through generations by cultural transmission, about the relationship of living beings (including humans) with one another and with their environment." (Berkes et al. 2000: 1252)

- "I use TEK to mean the knowledge and insights acquired through extensive observation of an area or a species." (Huntington 2000: 1270)

- "One definition of Traditional Ecological Knowledge is 'the sum of the data and ideas acquired by a human group on its environment resulting from the group's use and occupation of a specific region over many generations' (Mailhot 1994)." (Pierotti 2011: 9)

My goal is certainly not to be critical of Traditional Ecological Knowledge or its definitions, but rather to note that it should be even harder to define the more general notion of indigenous science than it is to define Traditional Environmental Knowledge.

\section{Putative myths in indigenous and western sciences}

Considering Indigenous science to be a bona fide form of science will not be easy, despite some impressive attempts (Colorado 1988, Baker 1996, Kimmerer 2002, Alessa 2009). "Unfortunately because EuroWestern ideas dominate the realm of science, much of Indigenous knowledge has been relegated as little more than mythology or folklore." (Rice n.d.: 3). As evidence that western scientists consider indigenous science to be a form of pseudoscience, I met huge resistance when proposing a new undergraduate biology course in indigenous perspectives in evolution and ecology. This seemed to me to be a reasonable course offering given that this is an active area of research and both evolution and ecology are largely observational (vice experimental) disciplines. My proposal was rejected because, "There were serious concerns about creating a precedent for 'Science' courses based on mythological and folklore traditions" (pers. comm., 2012). Yet I never mentioned myth nor folklore in the course proposal! Also notice the monolithic use of an uppercase ' $\mathrm{S}$ ' in 'Science'. Equating indigenous sciences with myth, folklore, or pseudoscience is anachronistic. At least until 'Karl Popper proposed 'falsifiability' as a demarcation criterion to separate scientific knowledge from nonscientific pretenders[,] attempts...to separate scientific from pseudo-scientific knowledge generally ended up classifying traditional knowledge as pseudoknowledge. Consequently, the problem of demarcating traditional knowledge from pseudo-science did not arise" (Bala and Gheverghese Joseph 2007: 42). My course proposal was also rejected because it would supposedly open the door for courses in climate change denial (incidentally, our university already offers one of those) and creationism. "When Western modern science is defined as universal it does displace revelation-based knowledge (i.e., creation science); however, it also displaces pragmatic local indigenous knowledge" (Snively and Corsiglia 2001: 6). But if we train students to think critically, they should be able to decide for themselves what is sense versus nonsense, science versus pseudoscience. I suggested that offering both indigenous and western science courses would be no different than theoretical physicists offering courses in both the Copenhagen and multiverse interpretations of quantum mechanics, but was told that real physicists do not discuss such matters, but leave that to philosophers. In a similar fashion, but not quite as draconian, there are endless debates as to whether evolution is driven more by nature or nurture. This is a false dichotomy, as shown by phenotypic plasticity, i.e. the study of the interactions between nature and nurture. Western and indigenous sciences provide different perspectives of the world, and the interactions between these two ways of knowing may well provide greater insight than any perspective on its own. While most of my science colleagues did not want to touch a course in indigenous science, I was eventually encouraged to offer this ecology and evolution course through the Indigenous Studies program, in Arts \& Social Sciences, even though it really should have been cross-listed in biology.

"[C]riticisms of the validity and utility of indigenous science misapprehend the structure and mechanics of indigenous oral information systems. These systems do not simply assert that mythic-magical forces cause and control events. Large numbers of indigenous peoples observe, interpret, and orally report nature exhaustively. Rather than writing about their findings, they may use metaphoric stories to compress and organize important information so that it can be readily stored and accessed." (Snively and Corsiglia 2001: 23).

Calling indigenous sciences myth and folklore is tantamount to calling them pseudoscience. Yet western sciences have as much myth and folklore as any other forms of science. Medieval medicine and its successors were based on the myth of four humours (yellow bile, black bile, blood, and phlegm), which were themselves based on the myth of the four elements of fire, earth, air, and water. Western medicine long believed that mercury was an effective cure for syphilis, which isn't altogether different from much contemporary medicine, such as chemotherapy and chiropractic techniques, which I do 
not consider to be science. Modern western science was born out of alchemy (Pigliucci and Boudry 2013). "Science' itself was born out of mysticism and the occult/esotericism, particularly via groups such as the Royal Society. Hermeticism infused the Renaissance and, for example, led to such occult theories as Newton's concept of gravity. The only difference between western science and all the other sciences and ways of knowing is that, uniquely, western science has cast this lineage as a negative-rejecting both the influence of religion and the influence of less 'savory' pursuits" (Mark Bonta, pers. comm. 2012). In the $20^{\text {th }}$ century, physics has been the driving force behind western philosophy of science. Yet, David Peat (2005) hints at an indigenous interpretation of quantum mechanics that may be no more nor less myth/folklore than the Copenhagen or multiverse interpretations.

There is plenty of myth and folklore in modern western ecology and evolution, not just in the reductionist fields of western physics, chemistry, and medicine. Ecological succession seems to be a myth. "There are various myths within western science itself that are being tested by Western scientists" (Cajete 2000: 3). Ecosystems have sometimes been considered fiction (Chase 1995). While many western ecologists would disagree about ecosystems being fictional or even metaphorical constructs, it is nonetheless difficult stipulating the boundaries of an ecosystem, such as who belongs or does not belong in one, how ecosystems change over time, whether any western ecological theory would need to be recast if ecosystems are fiction, and how ecosystems may be fuzzy constructs. A similar and related problem is encountered in measuring niche breadth and overlap. In a famous paper, Colwell and Futuyma (1971) provided methods for quantifying niche breadth and overlap, which are measures of interactions, but virtually everyone who cited their paper failed to invoke their methods or provide alternatives. From the 1850s thru 1980s, ecology and evolution were largely driven by the often mythical force called competition. Tennyson's famous folklore of "nature, red in tooth a claw" is still pervasive despite Gotelli and Grave's (1996) introduction of null models, despite Trivers and Hamilton's sociobiology of cooperation vis-à-vis kinship (Dugatkin 2006), and despite Wilson's (1975) evidence for multi-level selection. Despite Gould and Lewontin's (1979) famous (and inappropriately titled) spandrels paper, adaptation is still largely believed to drive evolution (full disclosure: in many contexts, I am an anti-adaptationist; see Gorelick 2009, Gorelick and Olson 2013). For example, Gould and Lewontin (1979) mocked the explanation for the short front limbs on Tyrannosaurus, which were purportedly used by a male to titillate a female during copulation, forgetting for the moment how heteronormative this image is. Kiplingesque just-so-stories still pervade evolutionary and ecological thinking, stories that could and probably should be considered folklore, but nonetheless pervade virtually all of our biology textbooks and many of our lectures. It is no coincidence that some of evolutionary biology's very best storytellers are also ardent adaptationists. This is a cursory list that eventually deserves a longer enumeration, possibly titled Anthology of Mythology of Ecology and Evolution.

\section{Knowing in two worlds: western and indigenous}

"Native and Western cultures, with their seemingly irreconcilably different ways of knowing and relating to the natural world, must search for common ground and a basis for dialogue" (Cajete 2006: 248). This is seemingly an even deeper rift than "the two cultures"sciences and humanities - that C.P. Snow (1956) alluded to. Western and indigenous science, "are usually perceived as two separate, distinct, and somewhat incompatible entities. Why is this? In part, it is simply stubbornness and fear on both sides. In practice they are very similar and in outputs (results) they are highly complementary because one works well at small scales and the other at large scales but in their origins, they differ" (Alessa 2009: 248).

The following quote seems equally true of both western and indigenous sciences, although written by a western philosopher of science (Lakatos 1974: 98):

A theory may be scientific even if there is not a shred of evidence in its favour, and it may be pseudoscientific even if all the available evidence is in its favour. That is, the scientific or non-scientific character of a theory can be determined independently of the facts. A theory is 'scientific' if one is prepared to specify in advance a crucial experiment (or observation) which can falsify it, and it is pseudoscientific if one refuses to specify such a 'potential falsifier'. But if so, we do not demarcate scientific theories from pseudoscientific ones, but rather scientific methods from non-scientific method.

Both western and indigenous sciences are ways of knowing in which practitioners predict crucial observations. "It is clear that in no sense is the Western scientific system truer than the Aboriginal one[s]. Both have pursued and developed certain dimensions of the truth at the expense of others, response to the economic, cultural and political demands of the cultures which produced them" (Christie 1993: 43).

Much of restoration ecology requires knowing in two worlds, realizing that ecology consists of interactions, including participation by humans (Christie 1993, Cajete 2000, Pierotti and Wildcat 2000). Robin Kimmerer's (2013) book Braiding Sweetgrass could have been titled Indigenous Restoration Ecology. There is little doubt that humans, wherever they have lived, 
have influenced ecosystems, often via managing fire and/or agriculture (Pyne 1982, Chase 1986, Shiva 1991). Management of forests and other ecosystems using fire has been one of the most productive collaborations between indigenous and western sciences (e.g. Kimmerer and Lake 2001, Baker 2003, Burr 2013).

Klinger (2006) provides an interesting case of integrating western and indigenous science in the biogeography of giant sequoias (Sequoiadendron giganteum). These massive trees have peculiar distributions both on large and small scales. Might island biogeography explain their distribution? Might humans have intentionally planted groves of these trees? Klinger hypothesized that humans may have planted individual trees in a circle, realizing that it might take seven or more human generations for the trees to form a shelter or natural cathedral. Unlike their coastal redwoods relatives (Sequoiadendron sempervirens), giant sequoias do not form fairy rings once a large tree dies (more accurately, once a large shoot dies). Klinger (2006) hypothesized about the odd distribution of fire scars on giant sequoias. On most species of trees, fire scars are far more common on the uphill side of the trunk because burning detritus rolls downhill and gets stuck at the base of their trunks. But, antithetically, giant sequoia scars apparently are more common on the downhill side of trunks, which Klinger hypothesized are caused by humans lighting small fires to help buttress the trunks. Finally, Klinger (2006) also describes a thin limestone layer in soil horizons surrounding many giant sequoias that may have been layers of mussel shell deposited by humans. He does not test these hypotheses, but shows the benefits of using both western and indigenous views for examining ecology of the world's most massive plants.

As another example of the extensive and unexpected interrelationships between organisms, indigenous observers noted a negative correlation between numbers of beavers and belugas. Their causal explanation was that beavers dam streams and thereby degrade and decrease the number of suitable spawning grounds for anadromous salmon, reducing local saltwater salmon populations, which are a major food source for belugas (Huntington 2000). While this hypothesis has not been tested by western scientists, it shows the value in indigenous science for generating theories that can be tested by western science, and probably has long ago been tested by indigenous scientists. The problem for western scientists is that indigenous testing of hypotheses is conveyed by oral history, not necessarily in written tomes.

Also note the important irony with belugas and beavers in that western science is usually (and probably mistakenly) envisioned as abstract, whereas indigenous science is envisioned as applied. Yet this example of belugas and beavers, in which abstract indirect causation is inferred by indigenous scientists based on very large-scale spatial and temporal observations, seems to be far more theoretical than what many western scientists infer.

Relational aspects of indigenous sciences put them way ahead of western sciences. Only recently have most western sciences come to appreciate the theoretical framework of relationships, such as of small-world networks (Watts and Strogatz 1998), relativity and quantum physics (Duran 2007), food webs (Paine 1980), and gene-gene interactions (multi-locus functional epistasis; Gorelick and Laubichler 2004, Hansen 2013). Thus, crucial theoretical contributions to science may come from either indigenous or western sciences.

At the beginning of this paper, I mentioned maples that produce edible sugar in spring. Such maples are known as the leaders of the tree nation in Haudenosaunee teachings, in part, because they are the first trees to awake at the end of winter and the first to provide food for humans and other animals. Since I moved to Canada, sugar maples have been my teachers-I share a home with six sugar maples that were probably born a half year before or after me. Maples show how exquisitely one can combine western and indigenous knowledge. While I am trained as a western American botanist and teach introductory botany, upon moving to Canada, I had no idea how maple trees worked. Why does sugary sap flow in sapwood (xylem), not inner bark (phloem)? Why does sugary sap only flow in sapwood before the tree leafs out? Why does the sugary sap only flow when it is below freezing at night and above freezing during the day, but only in late winter and early spring, not during autumn or during unseasonably mild days in midwinter? From western science, we learn about what pressurizes the vessels through which sugary sap flows (Cirelli et al. 2008). However, to western plant physiologists, there are "two topics that remain imperfectly understood and are perhaps better left unplumbed... First, how are embolisms repaired? Trees clearly can reestablish broken water columns each spring, but how they do it isn't entirely unclear, and not for want of effort by some clever and imaginative investigators. And second, what makes maple sap rise in the spring?... Roots aren't necessary for the process, but what's happening in the trunk remains uncertain" (Vogel 2012: 133; parenthetical remarks omitted). Even Steve Saupe (2009), a western botanist who studies maple syrup production, admitted that, "Each spring, syrup-makers head to the woods to collect sap from the sugar maple tree... Although this ritual has been practiced for many years since its discovery by Native Americans, surprisingly the actual mechanism responsible for sap flow is still something of a botanical mystery." Indigenous science tells us that the time to tap trees is when the squirrels starting chewing on the buds, often coming back the following morning to eat the 
crystallized and/or frozen sap that exuded the previous day (Kimmerer 2013). It also helps to look for wells in the snow around maples, which show that the trees are waking up and warming up, especially comparing maple snow wells to those surrounding tree species that wake up later in the season (Kimmerer 2013). The freeze/thaw cycles does more than just release sugary sap from storage cells, much like how freeze/thaw cycles break uninsulated plumbing. The freeze/thaw also helps pressurize the sugary sap. Those who collect sap in buckets hung from spiles also understand how the freeze/thaw cycle helps concentrate sugars, plunging our bare hands into the buckets each morning to remove and throw away the ice that formed overnight because the sugary syrup that remains in the buckets has a lower freezing point than that of water. Indigenous peoples knew that maple sugar was more than just a survival food at the end of hard winters insofar as maple sap that flowed from the trees was an important medicine that, amongst other things, prevented scurvy (Paul Skanks, pers. comm. 2014), which westerners would say is due to its high concentrations of vitamin $\mathrm{C}$ ( $\mathrm{Li}$ and Seeram 2010). Indigenous science and the maple trees have taught me far more about plant plumbing and physiology that I ever learned from western botany texts.

The best western science lacks jargon. Indigenous science also happens to be largely free of jargonunless you consider learning a new language to be learning jargon, which I do not. Maybe western scientists should not be so intensively taught hifalutin statistics, which are always jargon laden, but complement this with training in drawing useful graphs (Tukey 1977, Tufte 1983) and cartoons (e.g. Larry Gonick's cartoon guides to science) and writing metaphor-filled poetry (e.g. J.B.S. Haldane's (1964) autobiographical poem Cancer's a Funny Thing). And I say this as someone originally trained in mathematics and physics, who was taught rigour, but also taught the value of cartoon sketches of mathematical proofs. I am not certain why western sciences have shunned the roles of metaphors (although see Lakoff and Johnson 1980), while indigenous sciences have embraced metaphors. Western scientists should write for non-scientists and adopt more of an oral tradition to complement their published work, e.g. Science Cafés. Maybe oldfashioned, finely-honed lectures, oratories, are not such a horrendous way of conveying information, especially when used in conjunction with other traditions, such as sitting in a circle and slowly reaching consensus. Pigliucci and Boudry (2013) asked, "What happens when a theory adopts the external trappings of science, but without the substance?" They meant that pseudoscientists often hide behind jargon and statistics. But, turning their question around, maybe scientists need to eliminate as many of the trapping (i.e. jargon) as possible, thereby leaving charlatans no place to hide.
We need to distinguish sense from nonsense and distinguish science from pseudoscience. But we must also realize that westerners do not hold a monopoly on sense and sensible ideas. Judging from the environmental damage wrought by western societies, it seems that indigenous perspectives might be more sensible than western ones, at least when it comes to ecology. Sticking our necks out by making testable predictions that all can understand will keep us honest, keeping us doing science rather than pseudoscience. And sciences might truly benefit by being able to see in two or more worlds, which should include western and indigenous sciences. For me, western and indigenous science are both Bayesian undertakings, but with very different priors and sometimes with different data. The Bayesian updates, aka posterior probabilities, from western and indigenous sciences should be considered highly complementary, much as Euclidean geometry was needed for Newtonian physics and non-Euclidean was needed for the theory of relativity-both are important, but often for different applications. Bala and Gheverghese Joseph (2007: 42) in Race \& Class, a journal that biologists seldom read, thus provide a fitting epigraph and a reminder of how valuable it can be to be interdisciplinary and live in two worlds:

Once traditional cultures are seen as carriers of knowledge, even if this is not identified as scientific knowledge, the need arises to separate indigenous knowledge from pseudo-science and anti-science. It is important to appreciate the radical revision in our conceptions of knowledge implied by this simple demand. The issue is not the mere acknowledgement of the existence of two systems of knowledge concerning different domains of inquiry, as in acknowledging religious knowledge of the supernatural world alongside scientific knowledge of the natural world. It is also not about two systems of knowledge like science and metaphysics - one empirically testable and the other not testable so directly. Rather, it requires acknowledging that there are two systems of knowledge both of which are empirically testable and both of which are concerned with understanding and guiding practical activity within the same domain of phenomena.

\section{Acknowledgments}

I owe a special thanks to Haudenosaunee Elder Paul Skanks, who helped me take my first steps into understanding two worlds and to the students in my course in indigenous perspectives in ecology and evolution who taught me far more than I taught them. Thanks to Dan Longboat and his class at Trent University for a discussion of what is and isn't 
Indigenous science. Conversations with two geographers, Mark Bonta and Chris Burns, have been illuminating. This manuscript owes an enormous debt to the two reviewers: Emily Missyabit McAuley and Marie-Eve Drouin-Gagné. This work was supported by a Discovery Grant from the Natural Sciences and Engineering Research Council of Canada (NSERC).

\section{Referees}

Marie-Eve Drouin-Gagné - mariaevitadg@ hotmail.com Université Concordia

Emily Missyabit McAuley - emcauley@sfu.ca Simon Fraser University

\section{References}

Agrawal, A. 1995. Dismantling the divide between indigenous and scientific knowledge. Development and Change 26: 413-439. CrossRef

Aikenhead, G.S. and M. Ogawa. 2007. Indigenous knowledge and science revisited. Cultural Studies of Science Education 2: 539-620. CrossRef

Alessa, L.N. 2009. What is truth? Where western science and traditional knowledge converge. Pages 246-251 in M.S.T. Williams, editor. The Alaska Native reader: history, culture, politics, Duke University Press, Durham. CrossRef

Alfred, T. 1999. Peace, Power, Righteousness: an indigenous manifesto. Oxford University Press, Don Mills.

Baker, D. 1996. Does 'indigenous science' really exist? Australian Science Teachers' Journal 42: 18-20.

Baker, R. 2003. Yanyuwa classical burning regimes, Indigenous science and cross-cultural communication. Pages 198-204 in G. Cary, D. Lindenmayer, and S. Dovers, editors. Australia burning: fire ecology, policy and management issues, CSIRO Publishing, Collingwood, Victoria.

Bala, A. and G. Gheverghese Joseph. 2007. Indigenous knowledge and western science: the possibility of dialogue Race \& Class 49: 39-61. CrossRef

Berkes, F. 2012. Sacred ecology (3rd edition). Routledge, New York.

Berkes, F. and M.K. Berkes. 2009. Ecological complexity, fuzzy logic, and holism in indigenous knowledge. Futures 41: 6-12. CrossRef

Berkes, F., Colding, J., and C. Folke. 2000. Rediscovery of traditional ecological knowledge as adaptive management. Ecological Applications 10: 12511262. CrossRef

Blaut, J.M. 1993. The colonizer's model of the world: Geographical diffusionism and Eurocentric history. Guilford Press, New York.
Brown, J.W. 1975. Native American contributions to science, engineering, and medicine. Science 189: 38-40. CrossRef

Burr, J.L. 2013. Burning across boundaries: Comparing effective strategies for collaboration between fire management agencies and Indigenous communities. Occasion (Interdisciplinary Studies in the Humanities) 5: 1-16.

Cajete, G. 2000. Native science: natural laws of interdependence. Clear Light Publishers, Santa Fe.

Cajete, G. 2006. Western science and the loss of natural creativity. Pages 247-259 in Four Arrows (Wahinpke Topa), Don Trent Jacobs, editor. Unlearning the language of conquest: Scholars expose anti-Indianism in America, University of Texas Press, Austin, Texas.

Chase, A. 1986. Playing God in Yellowstone: the destruction of America's first national park. Atlantic Monthly Press, Boston.

Chase, A. 1995. In a dark wood: the fight over forests and the rising tyranny of ecology. Houghton Mifflin, Boston.

Christie, M.J. 1993. Aboriginal science for the ecologically sustainable future. Chain Reaction 68: 40-43.

Cirelli, D., Jagels, R., and M.T. Tyree. 2008. Toward an improved model of maple sap exudation: the location and role of osmotic barriers in sugar maple, butternut and white birch. Tree Physiology 28: 1145-1155. CrossRef

Colorado, P. 1988. Bridging Native science and Western science. Convergence 21: 49-68.

Colwell, R.K. and D.J. Futuyma. 1971. Measurement of niche breadth and overlap. Ecology 52: 567-576. CrossRef

Darwin, C.R. 1842. Structure and distribution of coral reefs. Smith, Elder and Co., London.

Darwin, C.R. 1859. On the origin of species by natural selection or the preservation of favoured races in the struggle for life. John Murray, London.

Diamond, J. 1997. Guns, germs, and steel: the fates of human societies. W W. Norton, New York.

Drouin-Gagne, M-E. 2014. Western and Indigenous sciences: colonial heritage, epistemological status, and contribution of a cross-cultural dialogue to science. Ideas in Ecology and Evolution 7: 56-61. CrossRef

Dugatkin, L.A. 2006. The altruism equation: seven scientists search for the origins of goodness. Princeton Unversity Press, Princeton.

Duran, P.H. 2007. On the cosmic order of modern physics and the conceptual world of the American Indian. World Futures: The Journal of Global Education 63: 1-27.

Feyerabend, P. 1975. Against method: outline of an anarchistic theory of knowledge. New Left Books, London. 
Feyerabend, P. 1987. Farewell to reason. Verso, London.

Feyerabend, P. 2010. Against method (4th edition). Verso, London.

Gagliano, M., Renton, M., Duvdevani, N., Timmins, M., and S. Mancuso. 2012. Out of sight but not out of mind: alternative means of communication in plants. PLoS One 7: e37382. CrossRef

Gelb, A. 1974. Applied optimal estimation. MIT Press, Cambridge.

George-Kanentiio, D. 1995. Iroquois population in 1995. Akwesasne Notes (New Series) 1: 61.

Gorelick, R. 2009. Evolution of cacti is largely driven by genetic drift, not selection. Bradleya 27: 41-52.

Gorelick, R. 2011. What is theory? Ideas in Ecology and Evolution 4: 1-10. CrossRef

Gorelick, R. 2012. Theory may not be definable and its development is not efficient. Ideas in Ecology \& Evolution 5: 25-26. CrossRef

Gorelick, R. and M.D. Laubichler. 2004. Decomposing multilocus linkage disequilibrium. Genetics 166: 1581-1583. CrossRef

Gorelick, R. and J. Carpinone. 2009. Origin and maintenance of sex: the evolutionary joys of self sex. Biological Journal of the Linnean Society 98: 707-728. CrossRef

Gorelick, R. and K. Olson. 2013. Polyploidy is genetic hence may cause non-adaptive radiations, whereas pseudopolyploidy is genomic hence may cause adaptive non-radiations. Journal of Experimental Zoology (Part B. Molecular and Developmental Evolution) 320B: 286-294. CrossRef

Gorelick, R. and T.E. Marler. 2014. Kin recognition by roots occurs in cycads and probably in conifers. Communicative \& Integrative Biology 7: e28009. CrossRef

Gotelli, N.J. and G.R. Graves. 1996. Null models in ecology. Smithsonian Institution Press, Washington DC.

Gould, S.J. and R.C. Lewontin. 1979. Spandrels of San Marco and the Panglosian paradigm: a critique of the adaptationist program. Proceedings of the Royal Society of London Series B-Biological Sciences 205: 581-598. CrossRef

Griffith, M.P., Noblick, L.R., Dowe, J.L., Husby, C.E., and M.A. Calonje. 2008. Cyclone tolerance in New World Arecaceae: Biogeographic variation and abiotic natural selection. Annals of Botany 102: 591-598. CrossRef

Grinde, D.A. 1977. The Iroquois and the founding of the American nation. Indian Historian Press, San Francisco.

Haldane, J.B.S. 1964. Cancer's a funny thing, New Statesman. 21 February 1964.
Hansen, T.F. 2013. Why epistasis is important for selection and adaptation. Evolution 67: 3501-3511. CrossRef

Holmes, L. 1996. Elders' knowledge and the ancestry of experience in Hawai'i. Ph.D dissertation. University of Toronto, Toronto.

Huntington, H.P. 2000. Using Traditional Ecological Knowledge in science: Methods and applications. Ecological Applications 10: 1270-1274. CrossRef

Idrobo, C.J. and R. Berkes. 2012. Pangnirtung Inuit and the Greenland shark: co-producing knowledge of a little discussed species. Human Ecology 40: 405414. CrossRef

Johansen, B.E. 1982. Forgotten founders: Benjamin Franklin, the Iroquois and the rationale for the American Revolution. Gambit, Ipswich.

Kawagley, A.O. 1995. A Yupiaq worldview: a pathway to ecology and spirit. Waveland Press, Prospect Heights, Illinois.

Kimmerer, R.W. 2002. Weaving traditional ecological knowledge into biological education: a call to action. BioScience 52: 432-438. CrossRef

Kimmerer, R.W. 2003. Gathering moss: a natural and cultural history of mosses. Oregon State University Press, Corvallis.

Kimmerer, R.W. 2013. Braiding sweetgrass: Indigenous wisdom, scientific knowledge and the teachings of plants. Milkweed Editions, Minneapolis.

Kimmerer, R.W. and F.K. Lake. 2001. Maintaining the mosaic: The role of indigenous burning in land management. Journal of Forestry 99: 36-41.

Klinger, L. 2006. Ecological evidence of large-scale silviculture by California Indians. Pages 153-165 in Four Arrows (Wahinpke Topa), Don Trent Jacobs, editor. Unlearning the language of conquest: Scholars expose anti-Indianism in America, University of Texas Press, Austin, Texas.

Lakatos, I. 1970. Falsification and the methodology of scientific research programmes. Pages 91-316 in I. Lakatos and A. Musgrave, editors. Criticism and the growth of knowledge, Cambridge University Press, Cambridge.

Lakatos, I. 1974. Science and pseudoscience. Pages 96102 in G. Vesey, editors. Philosophy in the open, Open University Press, Milton Keynes.

Lakoff, G. and M. Johnson. 1980. Metaphors we live by. University of Chicago Press, Chicago.

Law, J. 2004. After method: mess in social science research. Routledge, London.

Leahy, S. 2012. Wisdom of Elders better than science or the internet: They still know how to cook mammoth [ http://newswatch.nationalgeographic.com/2012/03/ 29/wisdom-of-elders-betterthan-science-or-theinternet-they-still-know-how-to-cook-mammoth/ ]. 
Li, L.Y. and N.P. Seeram. 2010. Maple syrup phytochemicals include lignans, coumarins, a stilbene, and other previously unreported antioxidant phenolic compounds. Journal of Agricultural and Food Chemistry 58: 11673-11679. CrossRef

Lobachevski, N. 1840 [1914]. Geometrical researches on the theory of parallels [translator: G. B. Halstead]. Open Court Publishing, La Salle, Illinois.

Mailhot, J. 1994. Traditional ecological knowledge: the diversity of knowledge systems and the study. Great Whale Public Review Support Office, Montréal.

McGrayne, S.B. 2011. The theory that would not die. Yale University Press, New Haven.

Moore, J.A. 1999. Science as a way of knowing: the foundations of modern biology. Harvard University Press, Cambridge.

Norton, B.G. 2005. Sustainability: a philosophy of adaptive ecosystem management. University of Chicago Press, Chicago. CrossRef

Paine, R.T. 1980. Food webs: linkage, interaction strength and community infrastructure. Journal of Animal Ecology 49: 667-685. CrossRef

Peat, D.F. 2005. Blackfoot physics: a journey into the Native American universe. Weiser Books, Boston.

Pierotti, R. 2011. Indigenous knowledge, ecology, and evolutionary biology. Routledge, New York.

Pierotti, R. and D. Wildcat. 2000. Traditional Ecological Knowledge: the third alternative. Ecological Applications 10: 1333-1340. CrossRef

Pigliucci, M. and M. Boudry. 2013. The dangers of pseudoscience, New York Times. 10 October 2013. [http://opinionator.blogs.nytimes.com/2013/10/10/th e-dangers-of-pseudoscience/?_r=0]

Popper, K.R. 1959 [1934]. The logic of scientific discovery. Basic Books, New York.

Pyne, S.J. 1982. Fire in America: a cultural history of wildland and rural fire. Princeton University Press, Princeton.

Reid, R. and S. Traweek. 2000. Doing science + culture: How cultural and interdisciplinary studies are changing the way we look at science and medicine. Routledge, London.

Rice, B. n.d. Balancing academia and Indigenous environmental peacebuilding: Is it too late?

Saupe, S.G. 2009. The mystery of maple sap flow, Yard and Garden News (University of Minnesota, Extension Service). [http://blog.lib.umn.edu/efans/ ygnews/2009/04/the_mystery_of_maple_sap_flow.h tml]

Shiva, V. 1991. The violence of the green revolution. Zed Books, London.

Snively, G. and J. Corsiglia. 2001. Discovering Indigenous science: implications for science education. Science Education 85: 6-34. CrossRef

Snow, C.P. 1956. The two cultures. New Statesman. 6 October 1956.
Taylor, C.A. 1996. Defining science: a demarcation of rhetoric. University of Wisconsin Press, Madison.

Tufte, E.R. 1983. The visual display of quantitative information. Graphics Press, Cheshire.

Tukey, J.W. 1977. Exploratory data analysis. AddisonWesley, Reading.

Usher, P.J. 2000. Traditional ecological knowledge in environmental assessment and management. Arctic 53: $183-193$.

Verran, H. 1998. Re-imagining land ownership in Australia. Postcolonial Studies 1: 237-254. CrossRef

Vogel, S. 2012. The life of a leaf. University of Chicago Press, Chicago. $\underline{\text { CrossRef }}$

Vogelsberger, M., Genel, S., Springel, V., Torrey, P., Sijacki, D., Xu, D., et al. 2014. Properties of galaxies reproduced by a hydrodynamic simulation. Nature 509: 177-182. CrossRef

Watts, D.J. and S.H. Strogatz. 1998. Collective dynamics of 'small-world' networks. Nature 393: 440-442. CrossRef

Wilson, D.S. 1975. Theory of group selection. Proceedings of the National Academy of Sciences of the United States of America 72: 143-146. CrossRef

Wilson, S. 2008. Research is ceremony: Indigenous research methods. Fernwood Publishing, Winnipeg.

\section{Response to referee}

I am in complete agreement with Marie-Eve DrouinGagné (2014), wishing I could have said things as well as she has. Maybe two heads are better than one or, in this instance, two knowledges from two very different perspectives are better than one. Colonial heritage has put blinders on me, blinders that I am not always cognizant of, despite my best efforts, which alone is a great reason to engage in a dialogue with scholars of indigenous epistemologies and ontologies.

Much of western philosophy and politics has been driven by the Doctrine of Discovery, by which the pope tried to obviate all other philosophies and obliterate other all peoples. As the U.S. Supreme Court appallingly said in interpreting the Doctrine of Discovery, "The right to govern may be the inevitable consequences of the right to acquire territory" (U.S. v Kagama, 119 U.S. 374, 378-379 (1885)). However, just because Europeans claimed that they were superior to indigenous peoples did not make them so.

Marie-Eve Drouin-Gagné (2014) mentions sociocultural evolution, which we too often forget is an important aspect of or abuse of evolutionary theory, one that Charles Darwin may have supported (Desmond and Moore 2009) and an idea certainly advocated by Herbert Spencer (1863 [1890]).

Probably the most important thing that Marie-Eve Drouin-Gagné (2014) broached was the different 
demarcations needed in indigenous and western philosophies. Not only do we want to differentiate science from pseudoscience, but we may also want to differentiate indigenous science from western science, religion from spirituality, indigenous science from indigenous religion, and indigenous science from indigenous pseudoscience. These are all really hard problems. We will only make progress in answering them if we realize that that these philosophical problems exist and are important. My contribution is merely to try applying these conundrums to ecology and evolution. Alas, in retrospect (hindsight always being 50:50), I wish Marie-Eve Drouin-Gagné had written the lead paper and I could have responded by sprinkling on the organismal biology applications. Regardless, as MarieEve Drouin-Gagné (2014) very wisely stated, this will be a complex but fruitful dialogue between indigenous and western (and other) knowledge systems.

Desmond, A. and Moore, J. 2009. Darwin's sacred cause: How a hatred of slavery shaped Darwin's views on human evolution. Houghton Mifflin Harcour, New York.

Drouin-Gagné, M-E. 2014. Western and Indigenous sciences: colonial heritage, epistemological status, and contribution of a cross-cultural dialogue to sciences. Ideas in Ecology and Evolution 7: 56-61. CrossRef

Spencer, H. 1863 [1890]. The principles of biology (volumes 1 and 2). Williams \& Norgate [Appleton], London [New York]. 